\title{
WARM CLIMATIC INTERVALS IN THE EASTERN ARCTIC DURING THE QUATERNARY: PALYNOLOGICAL DATA FROM LAKE EL'GYGYTGYN, NORTHERN CHUKOTKA
}

\begin{abstract}
A. V. Lozhkin', P. M. Anderson ${ }^{2}$
${ }^{I}$ North-East Interdisciplinary Scientific Research Institute n. a. N. A. Shilo, FEB RAS, Magadan

${ }^{2}$ Quaternary Research Center, University of Washington, Seattle WA, USA

E-mail: lozhkin@neisri.ru; pata@uw.edu

The continuous sediment record from Lake El'gygytgyn indicates that conifer forest characterized the warmest intervals during the Quaternary in northern Chukotka, where today herb and shrub tundra dominates. Most of these intervals occurred in the Early Pleistocene (e. g., marine isotope stage MIS93, MIS91, MIS81, MIS71) and are associated with pollen assemblages that indicate the widespread presence of light coniferous forest with Larix and tree Betula and Alnus. The most extreme warmth over the past $\sim 2.6$ Ma also occurred during the Pleistocene "ice ages". During MIS31 and MIS11, dark coniferous forest with Picea, Pinus, and Larix formed the regional vegetation, representing a northern range extension of $\sim 2000 \mathrm{~km}$ for some species. Relatively cool climates characterize the two most recent thermal maximum during MIS5 and the Early Holocene. Although Northern Hemisphere climates generally cooled throughout the Pleistocene, the El'gygytgyn data show the nonlinear nature of climate change and suggest a loss of arctic communities under future global warming.
\end{abstract}

Keywords: Pleistocene, Holocene, thermal maximum, coniferous forest, pollen analysis.

DOI: $10.34078 / 1814-0998-2020-1-74-80$

\section{INTRODUCTION}

The remarkable period within Earth's history, when glaciers became more extensive and persistent in the Northern Hemisphere and modern biocenoses developed, was recognized as early as 1759 , but the term "Quaternary" was not used until 1833 when it was first introduced by H. Raboul (Gibbard and Head, 2009). Initially the base of the Quaternary, or the Pliocene-Pleistocene boundary (the division between the Quaternary and Neogene periods; Fig. 1), was placed at 1.8 million years $(\mathrm{Ma})$. While the age of this boundary has long been debated, it became a particular focus in 1948, in part because new geological data indicated that the initial global cooling, a key characteristic of the Pleistocene, began in what was then classified as the Late Tertiary $(\sim 2.8-2.4$ Ma; Gibbard et al., 2010, Head and Gibbard, 2015). Consequently, many Quaternary scientists argued for an earlier basal age for the Quaternary, whereas Neogene specialists maintained that the original classification should stand. Extensive discussions by Cenozoic stratigraphers ultimately led to the definition of the Pliocene - Pleistocene boundary by the Executive Committee of the International Union of Geological Sciences (IUGS) as $2.588 \mathrm{Ma}$ based on the Gelasian (previously included as the latest age

(C) Ложкин А. В., Андерсон П. М., 2020 in the Pliocene) stratotype from the Vrica site in Calabria, southern Italy, supplemented with new data from Monte San Nicola, Sicily (Gibbard and Head, 2009; Gibbard et al., 2010; Head and Gibbard, 2015). The initiation of the Holocene, the most recent epoch within the Quaternary, was ratified by the IUGS as $11.7 \mathrm{cal} \mathrm{ka}$ (thousand calendar years before AD 2000) based on the NorthGRIP ice core from Greenland (Walker et al., 2009).

The Pleistocene epoch dominates the Quaternary both in terms of its relative length as compared to the Holocene, but also because of the extraordinary changes to the Earth's climate system that occurred between $\sim 2.6 \mathrm{Ma}$ and $11.7 \mathrm{cal} \mathrm{ka}$. Although conditions during the Early Pleistocene were generally colder than during the Late Pliocene, the major shifts in global climate occurred during the Early-to-Middle Pleistocene transition (EMPT, 1400-400 ka; McClymont et al., 2013; Head and Gibbard, 2015). This interval is characterized by the: i) increase in amplitude of climatic oscillations; ii) intensified cooling beginning $\sim 1200$; iii) increase in global ice volume $\sim 1250-700 \mathrm{ka}$; iv) progressively longer and stronger glaciations; and v) shorter interglaciations. The most extensive Quaternary glaciations occurred in the last $900 \mathrm{ka}$ during the Middle and Late Pleistocene (Head and Gibbard, 2015). Although much of the fascination with the Pleistocene relates to the 


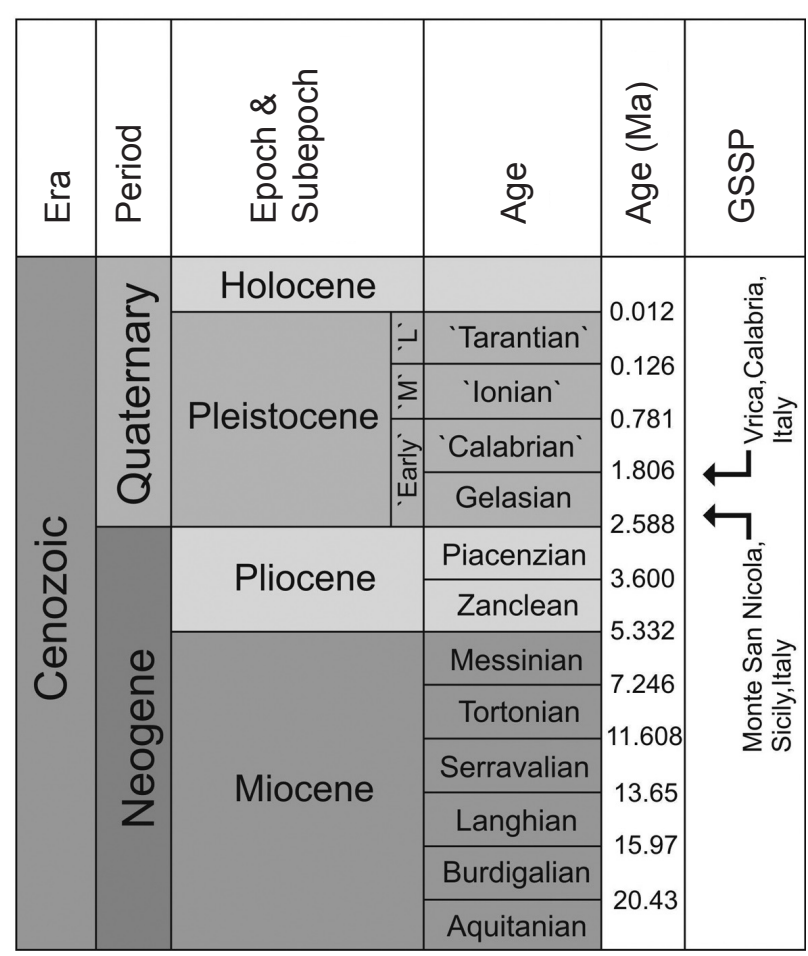

Fig. 1. Quaternary stratigraphic scheme. GSSP Global Stratotype Section and Point (GSSP) (Gibbard et al., 2010)

Puc. 1. Четвертичная стратиграфическая схема. GSSP - глобальная стратотипическая секция и местонахождение (Gibbard et al., 2010)

build-up of continental ice sheets, this epoch is also punctuated by milder intervals, some of which are characterized by extreme warmth in northern high latitudes (Lozhkin et al., 2007, 2013; Melles et al., 2012; Wennrich et al., 2016). Understanding the effects of warmer than present conditions on landscapes, particularly in the Arctic, has become a great priority in the scientific community as changes related to global warming are becoming increasingly evident (IPCC..., 2007). We highlight here several of these remarkable interglaciations (MIS93, MIS91, MIS81, MIS71, MIS31, MIS11, MIS5, and the most recent the postglacial thermal maximum (PGTM Postglacial thermal maximum); Table 1) by examining Quaternary-age palynological data from Lake El'gygytgyn, located in polar Chukotka $\left(67^{\circ} 30^{\prime} \mathrm{N}\right.$, $172^{\circ} 05^{\prime} \mathrm{E}, 492 \mathrm{~m}$ a. s. 1.). We focus on the thermal maxima within these warm intervals.

\section{STUDY SITE}

A 317-m composite sediment core from Lake El'gygytgyn provides an extraordinary, continuous record of changing environments over the last 3.6 Ma (Melles et al., 2012; Brigham-Grette et al., 2013; Wennrich et al., 2016). Formed by a meteorite impact, the $\sim 12 \mathrm{~km}$ wide lake occupies the center of $\mathrm{a} \sim 18 \mathrm{~km}$ wide crater, which lies within the Anadyr Plateau. The age of crater is based on an ${ }^{40} \mathrm{Ar} /{ }^{39} \mathrm{Ar}$ date $(3.58 \pm 0.04 \mathrm{Ma}$; Layer, 2000), whereas the core chronology itself relies primarily on its magnetostratigraphy, as further refined by aligning sediment characteristics (e. g., Si/Ti ratios, biogenic silica) with the marine isotope (Lisiecki $\&$ Raymo, 2005) and the $65^{\circ} \mathrm{N}$ summer insolation (Laskar et al., 2004) curves (see Nowaczyk et al., 2013 for more detail). Today mean annual, July, and January temperatures in the El'gygytgyn area are $-10.4^{\circ} \mathrm{C},+8^{\circ} \mathrm{C}$ and $-32^{\circ} \mathrm{C}$, respectively (http:// meteo.ru). Dry conditions in the crater prevail year around $(\sim 73-200 \mathrm{~mm}$ rainfall, $108 \mathrm{~mm}$ water equivalent snowfall; Nolan, 2013). Hypoarctic tundra characterizes the local vegetation and is dominated by a discontinuous cover of lichens and Poaceae (Kozhevnikov, 1993; Lozhkin et al., 2007). Woody plants are limited to low-growth forms of $\mathrm{Sa}$ lix krylovii and S. alaxensis and Betula exilis. These shrubs are found in protected areas with organic accumulation (e. g., along streams and terraces).

Table 1. Pollen percentages of conifer taxa (Lake El'gygytgyn) for select warm intervals of the Quaternary Таблица 1. Процентные содержания пылыцы хвойных таксонов (оз. Эльгыгытгын) для определенных интервалов потепления климата в четвертичный период

\begin{tabular}{|l|c|c|c|c|c|}
\hline \multicolumn{1}{|c|}{ MIS } & Age, ka & Subepoch & Pinus, $\%$ & Picea, $\%$ & Larix, $\%$ \\
\hline 93 & $2373-2387$ & Early Pleistocene & $50-60$ & 5 & $20-30$ \\
\hline 91 & $2333-2350$ & Early Pleistocene & $60-75$ & $5-10$ & 5 \\
\hline 81 & $2125-2146$ & Early Pleistocene & $50-65$ & 0 & $<2$ \\
\hline 71 & $1875-1898$ & Early Pleistocene & $15-40$ & $<2$ & $<2$ \\
\hline 31 & $1062-1081$ & Early Pleistocene & $\begin{array}{c}10-20 \\
\text { (one sample at 55) }\end{array}$ & 15 & $<2$ \\
\hline 11 & $374-424$ & Middle Pleistocene & 20 & $20-60$ & $<5$ \\
\hline 5 & $71-130$ & $\begin{array}{c}\text { Middle to Late } \\
\text { Pleistocene }\end{array}$ & 10 & 0 & $0 *$ \\
\hline & $13-10$ & $\begin{array}{c}\text { Late Pleistocene to } \\
\text { Early Holocene }\end{array}$ & 0 & 0 & 0 \\
\hline
\end{tabular}

* Larix found in permafrost core, El'gygytgyn crater.

** Larix found in outlet stream from El'gygytgyn Lake. 
In contrast, the vegetation of the Anadyr Plateau consists primarily of a continuous mosaic of low shrub and herb-dominated tundra with scattered $P i$ nus pumila and Duschekia fruticosa (shrub Alnus). To the north, wet to mesic tundra communities occur in the coastal lowlands. To the south, shrubs have an increased presence on the landscape, in optimal areas forming Pinus pumila-Duschekia fruticosa high shrub tundra. Larix cajanderi forest-tundra has established $\sim 150 \mathrm{~km}$ to the south and west of Lake El'gygytgyn, although the main body of the forest is $\sim 300-500 \mathrm{~km}$ away.

\section{TRENDS IN SELECT WARM-INTERVAL PALEOVEGETATION, LAKE EL'GYGYTGYN}

The warmest climates represented in the El'gygytgyn record occurred between 3.5 and $3.35 \mathrm{Ma}$, (the Piacenzian age of the Late Pliocene) when the regional vegetation was Picea-Larix-Pinus-AbiesTsuga forest (Andreev et al., 2014, 2016). These forests possibly resembled modern conifer forests of eastern Canada and are in stark contrast to the present-day hypoarctic tundra of the El'gygytgyn crater and the low shrub tundra of the surrounding Anadyr Plateau. As mentioned above, global coo-ling began prior to the Pleistocene. By the latest Pliocene, climates had deteriorated sufficiently to eventually eliminate Abies from the forest and cause a significant decrease in Picea. Tundra and forest/tundra communities became more common in northern Chukotka beginning $\sim 3.31 \mathrm{Ma}$. This change is reflected both in terms of the spatial extent of these vegetation types and in the number and length of periods when nonarboreal pollen dominated.

The warmest intervals recorded in the Quaternary sediments of Lake El'gygytgyn all share a common paleovegetational feature with the Late Pliocene in that they are characterized by the regional establishment of conifer forest (Lozhkin et al., 2007, 2017, 2019a, b; Melles et al., 2012; Brigham-Grette et al., 2013; Lozhkin and Anderson, 2013; Andreev et al., 2014, 2016; Zhao et al., 2015, 2017; Wennrich et al., 2016). By the Early Pleistocene ( 2.6 Ma), the role of conifers in the regional vegetation was greatly reduced as compared to the Pliocene and is indicative of the deteriorating climate. For example, the role of Pinus in the northern vegetation was greatly reduced by the Early Pleistocene, and Larix was the only conifer species to appear consistently in the El'gygytgyn record, occurring in both warm and cool intervals until the latest Pleistocene. The trend towards increasingly cool/dry climates and treeless landscapes through the Quaternary, with the eventual dominance of graminoid-Artemisia and Betula or Betula-Alnus tundra, is punctuated by the widespread establishment of conifer forests in northern Chukotka (e. g., MIS93, MIS91, MIS71, MIS31, and MIS11). The thermal maxima in the most recent in- terglaciations (MIS5, PGTM), in contrast, lack a significant conifer component.

The four earliest warm intervals of the Early Pleistocene are characterized by similar vegetation (Table 1; Andreev et al., 2014; Zhao et al., 2015; Lozhkin et al., 2019b; Lozhkin and Anderson, unpublished data). While there is general agreement that the regional vegetation was forest dominated by Larix, opinions differ concerning the composition of the forest communities. Unfortunately, the growth forms of the prevalent pollen taxa in these assemblages (i.e., Betula, Alnus and Pinus subg. Haploxylon) can not be reliably differentiated by their pollen morphology. Modern ecological associations suggest that the forest understory included shrubs of Betula, Alnus and Pinus pumila. Andreev et al. (2014) and Zhao et al. (2015) interpret the high Pinus percentages in MIS93, MIS91, and MIS81 as representing dense thickets of Pinus pumila in the forest understory and the presence of Pinus shrub tundra at sites beyond altitudinal treeline. Lozhkin and Anderson (unpublished data) suggested that while Pinus pumila was probably present, tree Pinus along with tree species of Betula and Alnus were important components of the MIS71 forest. Modest amounts of Picea pollen, particularly in MIS93 and MIS91, perhaps indicate the local establishment of the trees, but if so, their presence was limited.

Although these Early Pleistocene intervals indicate strong responses of the vegetation to interglacial conditions, these responses are less striking than that seen during the youngest of the Early Pleistocene (MIS31) and the older Middle Pleistocene (MIS11) warm events (Lozhkin and Anderson, 2013; Lozhkin et al., 2017, 2019a). During the thermal optima of these "super" interglaciations, dark coniferous forest again established in and around the El'gygytgyn crater. Members of this forest included Larix, Picea sect. Omorica (likely Picea ajanensis), Picea sect. Eupicea (possibly Picea obovata), and Pinus subg. Diploxylon (Pinus silvestris). Pinus subg. Haploxylon pollen could represent Pinus sibirica or Pinus koraiensis. The conifer element of these assemblages is similar to that in modern plant communities of Primor'ye and the Amur basin in southern regions of the Russian Far East (Korotky et al., 2005). This similarity would suggest that Betula and Alnus in the pollen spectra includes tree species, which likely mixed with Larix occupied the most favorable settings along warmer southern and eastern slopes within the crater and the valleys of the Anadyr Plateau. Picea and Pinus trees were probably restricted to the cooler and wetter northern and western slopes, possibly with Pinus pumila thickets at highest elevations. The extremely low percentages of herb pollen $(<5 \%$ of total arboreal and nonarboreal pollen) suggests that the conifer forest was closed and extended to higher elevation sites both within the crater and on 
the Plateau. These low percentages might also indicate paucity or absence of Pinus pumila in the forest understory, as the shrub requires an open canopy.

The climatic optimum of MIS5, unlike the above warm intervals, lacks conifer pollen (note: Larix pollen was found in a permafrost core taken adjacent to the lake; Andreev et al., 2012), but like these earlier interglaciations, Betula and Alnus pollen is abundant (Lozhkin et al., 2007; Lozhkin and Anderson, 2013). The data from the Lake El'gygytgyn core suggests the presence of Betula-Alnus forest mixed with shrub tundra. Data from riverine sections, which tend to have few radiocarbon dates but whose regional stratigraphy indicates their deposition during the last interglaciation, suggest the establishment of open Betula forest in the Anadyr basin and Larix-BetulaAlnus forest with Pinus pumila in northern Chukotka.

The PGTM is not clearly defined in the El'gygytgyn pollen record, although Larix macrofossils were found in an exposure along the lake's outlet stream (Shilo et al., 2008). However, analog analyses suggest increased summer and winter warmth and greater summer precipitation between 9.6-12.7 ka cal (Lozhkin et al., 2007; Lozhkin and Anderson, 2013). Macrofossils from this time indicate the presence of tree Salix and Alnus beyond modern latitudinal treeline in northern Chukotka (Lozhkin, 1993). Biome analysis of late glacial assemblages from across Beringia indicates the dominance of deciduous forest and forest-tundra between 13 and 10 cal ka (Edwards et al., 2005).

\section{CONCLUSIONS}

Interglacial thermal maxima throughout the Pleistocene are marked by the expansion of conifer forests within the El'gygytgyn crater and surrounding Anadyr Plateau. For most intervals (e. g., MIS93, MIS91, MIS81, MIS71, MIS5) the vegetation was a cold deciduous or light coniferous forest. Larix was the dominant component, but the forest probably also included tree species of Betula and Alnus. However, in the extreme or "super" interglaciations of (MIS31, MIS11) a cold evergreen or dark coniferous forest of Larix, Picea (possibly Picea ajanensis and Picea obovata), and Pinus (Pinus silvestris and Pinus koraiensis or Pinus sibirica) characterized the vegetation of northern Chukotka and represent the mildest regional climates of the Quaternary. The Holocene thermal maximum is poorly recorded in the El'gygytgyn pollen record suggesting a more modest warming as compared to the Pleistocene. Other paleobotanical data from northern Chukotka, howe-ver, indicate a latitudinal extension of treeline and presence of a cold deciduous forest of Larix, Betula, and Alnus in areas that are now shrub tundra.

Despite the general characterization of the Pleistocene as a time of extensive and persistent glaci- ation, the Lake El'gygytgyn pollen data indicate that the warmest and wettest climates (i. e., MIS31, MIS11) of the last 2.6 Ma occurred during the "ice ages" and not the Holocene. The El'gygytgyn record further suggests that the two most recent thermal maxima (i. e., MIS5.5, PGTM) are relatively cool compared to the warm intervals of the Early Pleistocene and certainly as compared to the "super" interglaciations. Melles et al. (2012) speculated that high levels of greenhouse gases and acidification of the oceans were significant factors influencing the extreme warmth of MIS31 and MIS11. The effects of increasing greenhouse gases and ocean acidification are being seen today in northern regions (e. g., reduced extent and duration of sea ice). Additionally, linked climate and vegetation models show the strong likelihood of significant changes in the composition and structure of arcto-boreal vegetation as greenhouse gas emissions rise (Nolan et al., 2018). If the Lake El'gygytgyn data provide any insight to the extent of possible vegetation response to a warm earth scenario, arctic vegetation will disappear from northeasternmost Asia to be replaced by a PiceaLarix-Pinus forest.

Acknowledgements. This research was funded by the Russian Fund for Basic Research (Research project No. 19-05-00477). Coring operations were supported by the ICDP, the Far East Branch of the Russian Academy of Sciences, the Russian Foundation for Basic Research, the U. S. National Science Foundation, the German Federal Ministry of Education and Research, the Alfred Wegener Institute and Helmholtz Centre Potsdam, and the Austrian Federal Ministry of Science and Research.

\section{REFERENCES}

Andreev, A. A.; Morozova, E.; Fedorov, G.; Schmirrmeister, L.; Bobrov, A. A.; Kienast, F.; Schwamborn, G., 2012, Vegetation History of Central Chukotka Deduced from Permafrost Palaeoenvironmental Records from El'gygytgyn Impact Crater, Climate of the Past, 8, 1287-1300.

Andreev, A. A.; Tarasov, P. E.; Wennrich, V.; Melles, M., 2016, Millennial-Scale Vegetation Changes in the Northeastern Russian Arctic during the Pliocene/Pleistocene Transition (2.7-2.5 Ma) Inferred from the Pollen Record of Lake El'gygytgyn, Quaternary Science Reviews, 147, 245-256.

Andreev, A. A.; Tarasov, P.E.; Wennrich, V.; Raschke, E.; Herzschuh, U.; Nowaczyk, N. R.; Brigham-Grette, J.; Melles, M., 2014, Late Pliocene and Early Pleistocene Vegetation History of Northeastern Russian Arctic Inferred from the Lake El'gygytgyn Pollen Record, Climate of the Past, 10, 1017-1039.

Brigham-Grette, J.; Melles, M.; Minyuk, P.; Andreev, A.; Tarasov, P.; Deconto, R.; Koenig, S.; Nowaczyk, N.; Wennrich, V.; Rosen, P.; Halti-Hovi, E.; Cook, T.; Gebhardt, C.; Meyer-Jacob, C.; Synder, J.; Herzschuh, U., 2013, Pliocene Warmth, Extreme Polar Amplification, and Stepped Pleistocene Cooling Recorded in NE Russia, Science, 340, 1421-1427. 
Edwards, M. E.; Brubaker, L. B.; Anderson, P. M.; Lozhkin, A. V., 2005, Functionally Novel Biomes: A Response to Past Warming in Beringia, Ecology, 86, 1696 1703.

Gibbard, P.; Head, M. J., 2009, The Definition of the Quaternary System / Era and the Pleistocene Series/ Epoch, Quaternaire, 20, 125-133.

Gibbard, P. L.; Head, M. J.; Walker, M. J. C., 2010, And the Subcommission on Quaternary Stratigraphy, Formal Ratification of the Quaternary System / Period and the Pleistocene Series / Epoch with a Base at 2.58 Ma, Journal of Quaternary Science, 25 (2), 96-102.

Head, M. J.; Gibbard, P. I., 2015, Early-Middle Pleistocene Transitions: Linking Terrestrial and Marine Realms, Quaternary International, 389, 7-46.

IPCC Fourth Assessment Report, Climate Change: the AR4 Synthesis Report, 2007, Ed. R. K. Pachauri, IPCC Geneva, Switzerland.

Kozhevnikov, Yu. P., 1993, Vascular Plants Near El'gygytgyn, Eds. V. F. Bely \& I. A. Chereshnev, Natural Depression El'gygytgyn (Problems of Study and Protection), Magadan, IBPN FEB RAS, 62-82 [In Russian].

Korotky, A. M.; Anderson, P. M.; Lozhkin, A. V.; Matrosova, T. V.; Solomatkina, T., B.; Brown, T. A.; Brubaker, L. B.; Grebennikova, T. A.; Mokhova, L. M.; Hu, F. S., 2005, Characteristics of the Holocene Environmental History of the Sikhote-Alin Range (Primorsky Kray) from Lake Sediments, Ed. V. Ye. Glotov, Pages from Quaternary History Northeast Asia, Magadan, NEISRI FEB RAS, 70-86 [In Russian].

Laskar, J.; Robutel, P.; Joutel, F.; Gastineau, M.; Correia, A. C. M.; Levard, B., 2004, A Long-term Numerical Solution for the Insolation Quantities of the Earth, Astronomy \& Astrophysics, 428, 261-285.

Layer, P. W., 2000, Argon-40/Argon-39 Age of the El'gygytgyn Impact Event, Chukotka, Russia, Meteoritics \& Planetary Science, 35, 591-599.

Lisiecki, L. E.; Raymo M. E., 2005, A PliocenePleistocene Stack of 57 Globally Distributed Benthic $\delta^{18} \mathrm{O}$ Records, Paleoceanography, 20, PA1003, DOI: 10.1029/2004PA001071

Lozhkin, A. V., 1993, Geochronology of Late Quaternary Events in Northeastern Russia, Radiocarbon, 35, 429-433.

Lozhkin, A. V.; Anderson, P. M., 2013, Vegetation Responses to Interglacial Warming in the Arctic, Examples from Lake El'gygytgyn, Far East Russian Arctic, Climate of the Past, 9, 1211-1219.

Lozhkin, A. V.; Anderson, P. M.; Matrosova, T. V.; Minyuk, P. S., 2007, The Pollen Record from El'gygytgyn Lake: Implications for Vegetation and Climate Histories of Northern Chukotka Since the Late Middle Pleistocene, Journal of Paleolimnology, 37, 135-153.

Lozhkin, A. V.; Anderson, P. M.; Minyuk, P. S.; Korzun, Yu. A.; Nedorubova, E. Yu.; Kirillova, M. A., 2019a, Environmental Changes in Arctic Chukotka during Marine Isotope Stages 31-38: Implications for the Early to Middle Pleistocene Transition, Boreas, https://doi. org/10.1111/bor.12413

Lozhkin, A. V.; Andreev, A. A.; Anderson, P. M.; Korzun, Yu. A.; Nedorubova, E. Yu., 2019b, Vegetation of the Eastern Arctic between 2.595-2.554 Ma (Data from Lake El'gygytgyn, North-East Russia), Bulletin of the North-East Science Center, 4, 38-46, DOI: 10.34078/1814-0998-20194-38-46
Lozhkin, A. V.; Minyuk, P. S.; Anderson, P. M.; Nedorubova, E. Yu.; Korzun, Yu. A., 2017, Variability in Landscape and Lake System Responses to Glacial and Interglacial Climates during the Middle Pleistocene Based on Palynological and Geochemical Data from Lake El'gygytgyn, Eastern Arctic, Review of Palaeobotany and Palynology, 246, 1-13.

McClymont, E. I.; Sosdian, S. M.; Rosell-Mele, A.; Rosenthal, Y., 2013, Pleistocene Sea-Surface Temperature Evolution: Early Cooling, Delayed Glacial Intensification, and Implications for the Mid-Pleistocene Climate Transition, Earth-Science Reviews, 123, 173-193.

Melles, M.; Brigham-Grette, J.; Minyuk, P.S.; Nowaczyk, N.R.; Wennrich, V.; DeConto, R. M.; Anderson, P.M.; Andreev, A. A.; Coletti, A.; Cook, T. L.; Haltia-Hovi, E.; Kukkonen, M.; Lozhkin, A. V.; Rosén, P.; Tarasov, P.; Vogel, H.; Wagner, B., 2012, 2.8 Million Years of Arctic Climate Change from Lake El'gygytgyn, NE Russia, Science, 337, 315-320.

Nolan, M., 2013, Quantitative and Qualitative Constraints on Hind-Casting the Formation of Multiyear Lake-Ice Cores at Lake El'gygytgyn, Climate of the Past, 9, 1253-1269.

Nolan, C.; Jackson, S. T.; Overpeck, J. T.; Allen, J. R. M.; Anderson P. M.; Betancourt, J. L.; Binney, H. A.; Brewer, S.; Bush, M. B.; Chase, B. M.; Djamali, M.; Dodson, J.; Edwards, M.; Gosling, W. D.; Haberle, S.; Hotchkiss, S. C.; Huntley, B.; Ivory, S. J.; Kershaw, A. P.; Latorre, C.; Leydet, M.; Lézine, A.; Liu, K.; Liu, Y.; Lozhkin, A. V.; McGlone, M. S.; Marchant, R. A.; Moreno, P. I.; Müller, S.; Otto-Bliesner, B. L.; Shen, C.; Stevenson, J.; Tarasov, P. E.; Vincens, A.; Weng, C.; Xu, Q.; Zheng, $Z$., 2018, Past and Future Global Transformation of Terrestrial Ecosystems under Climate Change, Science, 361, 920-925.

Nowaczyk, N. R.; Haltia, E. M.; Ulbricht, D.; Wennrich, V.; Sauerbrev, M. A.; Rosen, P.; Vogel, H.; Francke, A.; Meyer-Jacob, C.; Andreev, A. A.; Lozhkin, A. V., 2013, Chronology of Lake El'gygytgyn Sediments - a Combined Magnetostratigraphic, Palaeoclimatic and Orbital Tuning Study Based on Multi-Parameter Analyses, Climate of the Past, 9, 2413-2432.

Shilo, N. A.; Lozhkin, A. V.; Anderson, P. M.; Vazhenina, L. N.; Glushkova, O. Yu.; Matrosova, T. V., 2008, New Data about the Expansion of Larix gmelinii to Arctic Regions of Beringia during the Early Holocene, Doklady Akademiyi Nauk, 422 (5), 1-3 [In Russian].

Walker, M.; Johnsen, S.; Rasmussen, S. O.; Popp, T.; Steffensen, J.-P.; Gibbard, P.; Hoek, W.; Lowe, J.; Andrews, J.; Bjorck, S.; Cwynar, L. C.; Hughen, K.; Kershaw, P.; Kromer, B.; Litt, T.; Lowe, D. J.; Nakagawa, T.; Newnham, R.; Schwander, J., 2009, Formal Definition and Dating of the GSSP (Global Stratotype Section and Point) for the Base of the Holocene Using the Greenland NGRIP Ice Core and Selected Auxiliary Records, Journal of Quaternary Science, 24, 3-17.

Wennrich, V.; Andreev, A.; Tarasov, P.; Fedorov, G., Zhao, W.; Gerhardt, C.; Meyer-Jacob, C.; Synder, J.; Nowaczyck, N.; Chaplin, B.; Anderson, P.; Lozhkin, A.; Minyuk, P.; Koeberl, C.; Melles, M., 2016, Impact Processes, Permafrost Dynamics, and Climate and Environmental Variability in the Terrestrial Arctic as Inferred from the Unique 3.6 myr Record of Lake El'gygytgyn, Far East Russia - a Review, Quaternary Science Reviews, 147, 221-244. 
Zhao, W. W.; Andreev, A. A.; Wennrich, V.; Tarasov, P. E.; Anderson, P.; Lozhkin, A. V.; Melles, M., 2015, The Réunion Subchron Vegetation and Climate History of the Northeastern Russian Arctic Inferred from the Lake El'gygytgyn Pollen Record, Palaeogeography, Palaeoclimatology, Palaeoecology, 436, 167-177.
Zhao, W.W.; Tarasov, P.E.; Lozhkin,A.V.;Anderson,P.M.; Andreev, A. A.; Korzun, Yu. A.; Melles, M.; Nedorubova, E. Yu.; Wennrich, V., 2017, High-Latitude Vegetation and Climate Changes during the Mid-Pleistocene Transition Inferred from a High-Resolution Palynological Record from Lake El'gygytgyn, Northeastern Siberia, Boreas, 47, 137-149.

Received 16.09.2019

Received after revision 01.10.2019

\title{
ИНТЕРВАЛЫ ПОТЕПЛЕНИЯ КЛИМАТА В ВОСТОЧНОЙ АРКТИКЕ В ЧЕТВЕРТИЧНЫЙ ПЕРИОД: ПАЛИНОЛОГИЧЕСКИЕ ДАННЫЕ ОЗЕРА ЭЛЬГЫГЫТГЫН, СЕВЕРНАЯ ЧУКОТКА
}

\author{
А. В. Ложкин ${ }^{1}$, П. М. Андерсон ${ }^{2}$ \\ ${ }^{I}$ ФГБУН Северо-Восточный комплексный научно-исследовательский институт \\ им. Н. А. Шило ДВО РАН, г. Магадан \\ Вашингтонский университет, факультет наук о Земле и Космосе, \\ Центр четвертичных исследований, г. Сиэтл, США \\ E-mail: pata@u.washington.edu; lozhkin@neisri.ru
}

\begin{abstract}
Непрерывные палинологические данные осадков оз. Эльгыгытгын показывают, что хвойный лес был характерен для теплых интервалов четвертичного периода на севере Чукотки, где сегодня преобладают травянистые и кустарниковые тундры. Большинство таких интервалов относятся к раннему плейстоцену (например, морские изотопные стадии MIS93, MIS91, MIS81, MIS71) и ассоциируют с пыльцевыми спектрами, которые указывают на широкое распространение светлохвойных лесов с Larix и, возможно, с древовидными Betula и Alnus. Самые экстремальные потепления за последние 2.6 млн лет происходили также и в плейстоценовые «ледниковые периоды». Во время MIS31 и MIS11 темнохвойный лес с Picea, Pinus и Larix формировал региональную растительность, представляющую расширение северного ареала примерно на 2000 км для некоторых видов. Относительно прохладный климат характеризует два самых последних максимума тепла во время МИС5 и раннего голоцена. Хотя климаты Северного полушария в целом холодные в течение плейстоцена, данные оз. Эльгыгытгын показывают нестабильность изменения климата и позволяют предположить, что арктические сообщества могут исчезнуть в результате глобального потепления в будущем.
\end{abstract}

Ключевые слова: плейстоцен, голоцен, термический максимум, хвойный лес, анализ пыльцы.

\section{ЛИТЕРАТУРА}

Кожевников Ю. П. Сосудистые растения в районе озера Эльгыгытгын // Природа впадины озера Эльгыгытгын. Магадан : ИБПС ДВО РАН, 1993. С. 62-82.

Короткий А. М., Андерсон П. М., Ложкин А. В., Матросова Т. В., Соломаткина Т. Б., Браун Т. А., Брубейкер Л. Б., Гребенникова Т. А., Мохова Л. М., $X y \Phi$. С. Особенности эволюции природной среды хр. Сихотэ-Алинь (Приморский край) в голоцене по данным озерных отложений // Страницы четвертичной истории Северо-Восточной Азии / ред. В. Е. Глотов. Магадан : СВКНИИ ДВО РАН, 2005. С. 70-86.

Шило Н. А., Ложкин А. В., Андерсон П. М., Важенина Л. Н., Глушкова О. Ю., Матросова Т. В. Первые данные об экспансии Larix gmelinii (Rupr.) Rupr. в арктические районы Берингии в раннем голоцене // Доклады Академии наук. 2008. Т. 422, № 5. C. 680-682.

Andreev A. A., Tarasov P. E., Wennrich V., Raschke E., Herzschuh U., Nowaczyk N. R., Brigham-Grette J., Melles $M$. Late Pliocene and early Pleistocene vegetation his- tory of northeastern Russian Arctic inferred from the Lake El'gygytgyn pollen record // Climate of the Past. 2014. Vol. 10 P. 1017-1039.

Andreev A. A., Tarasov P. E., Wennrich V., Melles M. Millennial-scale vegetation changes in the north-eastern Russian Arctic during the Pliocene / Pleistocene transition (2.7-2.5 Ma) inferred from the pollen record of Lake El'gygytgyn // Quaternary Science Reviews. 2016. Vol. 147. P. 245-256.

Andreev A. A., Morozova E., Fedorov G., Schmirrmeister L., Bobrov A. A., Kienast F., Schwamborn G. Vegetation history of central Chukotka deduced from permafrost palaeoenvironmental records from El'gygytgyn impact crater // Climate of the Past. 2012. Vol. 8. P. 1287-1300.

Brigham-Grette J., Melles M., Minyuk P., Andreev A., Tarasov P., Deconto R., Koenig S., Nowaczyk N., Wennrich V., Rosen P., Halti-Hovi E., Cook T., Gebhardt C., Meyer-Jacob C., Synder J., Herzschuh U. Pliocene warmth, extreme polar amplification, and stepped Pleis- 
tocene cooling recorded in NE Russia // Science. 2013. Vol. 340. P. 1421-1427.

Edwards M. E., Brubaker L. B., Anderson P. M., Lozhkin $A$. $V$. Functionally novel biomes: A response to past warming in Beringia // Ecology. 2005. Vol. 86. P. 1696-1703.

Gibbard P. L., Head M. J., Walker M. J. C., and the Subcommission on Quaternary Stratigraphy. Formal ratification of the Quaternary System / Period and the Pleistocene Series / Epoch with a base at 2.58 Ma // Journal of Quaternary Science. 2010. Vol. 25 (2). P. 96-102.

Gibbard P., Head M. J. The definition of the Quaternary system/era and the Pleistocene series/epoch // Quaternaire. 2009. Vol. 20. P. 125-133.

Head M. J., Gibbard P. I. Early-Middle Pleistocene transitions: Linking terrestrial and marine realms // Quaternary International. 2015. Vol. 389. P. 7-46.

IPCC Fourth Assessment Report // Climate change: the AR4 synthesis report / ed. R. K. Pachauri. IPCC Geneva, Switzerland. 2007.

Laskar J., Robutel P., Joutel F., Gastineau M., Correia A. C. M., Levard B. A long-term numerical solution for the insolation quantities of the Earth // Astronomy \& Astrophysics. 2004. Vol. 428. P. 261-285.

Layer P. W. Argon-40/argon-39 age of the El'gygytgyn impact event, Chukotka, Russia // Meteoritics \& Planetary Science. 2000. Vol. 35. P. 591-599.

Lisiecki L. E., Raymo M. E. A Pliocene-Pleistocene stack of 57 globally distributed benthic $\delta^{18} \mathrm{O}$ records // Paleoceanography. 2005. Vol. 20. PA1003. DOI: 10.1029/2004PA001071.

Lozhkin A. V. Geochronology of Late Quaternary events in Northeastern Russia // Radiocarbon. 1993. Vol. 35. P. 429-433.

Lozhkin A. V., Anderson P. M., Minyuk P. S., Korzun Yu. A., Nedorubova E. Yu., Kirillova M. A. Environmental changes in Arctic Chukotka during Marine Isotope Stages 31-38: implications for the Early to Middle Pleistocene transition // Boreas. 2019a. https://doi.org/10.1111/ bor. 12413

Lozhkin A. V., Anderson P. M., Matrosova T. V., Minyuk $P$. S. The pollen record from El'gygytgyn Lake: implications for vegetation and climate histories of northern Chukotka since the late middle Pleistocene // Journal of Paleolimnology. 2007. Vol. 37. P. 135-153.

Lozhkin A. V., Minyuk P. S., Anderson P. M., Nedorubova, E. Yu.; Korzun, Yu. A. Variability in landscape and lake system responses to glacial and interglacial climates during the Middle Pleistocene based on palynological and geochemical data from Lake El'gygytgyn, Eastern Arctic // Review of Palaeobotany and Palynology. 2017. Vol. 246. P. 1-13.

Lozhkin A. V., Andreev A. A., Anderson P. M., Korzun Yu. A., Nedorubova E. Yu. Vegetation of the Eastern Arctic between 2.595-2.554 Ma (Data from Lake El'gygytgyn, North-East Russia) // Bulletin of the North-East Science Center. 2019b. Vol. 4. P. 38-46. DOI: 10.34078/18140998-2019-4-38-46

Lozhkin A. V., Anderson P. M. Vegetation responses to interglacial warming in the Arctic, examples from Lake El'gygytgyn, Far East Russian Arctic // Climate of the Past. 2013. Vol. 9. P. 1211-1219.

McClymont, E. I., Sosdian S. M., Rosell-Mele A., Rosenthal $Y$. Pleistocene sea-surface temperature evolu- tion: early cooling, delayed glacial intensification, and implications for the mid-Pleistocene climate transition // Earth-Science Reviews. 2013. Vol. 123. P. 173-193.

Melles M., Brigham-Grette J., Minyuk P. S., Nowaczyk N. R., Wennrich V., DeConto R. M., Anderson P. M., Andreev A. A., Coletti A., Cook T. L., Haltia-Hovi E., Kukkonen M., Lozhkin A. V., Rosén P., Tarasov P., Vogel H., Wagner, B. 2.8 Million Years of Arctic Climate Change from Lake El'gygytgyn, NE Russia // Science. 2012. Vol. 337. P. 315-320.

Nolan C., Jackson S. T., Overpeck J. T., Allen J. R. M., Anderson P. M., Betancourt J. L., Binney H. A., Brewer S., Bush M. B., Chase B. M., Djamali M., Dodson J., Edwards M., Gosling W. D., Haberle S., Hotchkiss S. C., Huntley B., Ivory S. J., Kershaw A. P., Latorre C., Leydet M., Lézine A., Liu K., Liu Y., Lozhkin A. V., McGlone M. S., Marchant R. A., Moreno P. I., Müller S., Otto-Bliesner B. L., Shen C., Stevenson J., Tarasov P. E., Vincens A., Weng $C$., $X u$ $Q$., Zheng $Z$. Past and future global transformation of terrestrial ecosystems under climate change // Ibid. 2018. Vol. 361. P. 920-925.

Nolan M. Quantitative and qualitative constraints on hind-casting the formation of multiyear lake-ice cores at Lake El'gygytgyn // Climate of the Past. 2013. Vol. 9. P. $1253-1269$.

NowaczykN. R., Haltia E.M., UlbrichtD., Wennrich V., Sauerbrev M. A., Rosen P., Vogel H., Francke A., MeyerJacob C., Andreev A. A., Lozhkin A. V. Chronology of Lake El'gygytgyn sediments a combined magnetostratigraphic, palaeoclimatic and orbital tuning study based on multi-parameter analyses // Ibid. 2013. Vol. 9. P. 24132432.

Walker M., Johnsen S., Rasmussen S. O., Popp T., Steffensen J.-P., Gibbard P., Hoek W., Lowe J., Andrews J., Bjorck S., Cwynar L. C., Hughen K., Kershaw P., Kromer B., Litt T., Lowe D. J., Nakagawa T., Newnham R., Schwander J. Formal definition and dating of the GSSP (Global stratotype section and point) for the base of the Holocene using the Greenland NGRIP ice core and selected auxiliary records // Journal of Quaternary Science. 2009. Vol. 24. P. 3-17.

Wennrich V., Andreev A., Tarasov P., Fedorov G., Zhao W., Gerhardt C., Meyer-Jacob C., Synder J., Nowaczyck N., Chaplin B., Anderson P., Lozhkin A., Minyuk P., Koeberl C., Melles M. Impact processes, permafrost dynamics, and climate and environmental variability in the terrestrial Arctic as inferred from the unique 3.6 myr record of Lake El'gygytgyn, Far East Russia a review // Quaternary Science Reviews. 2016. Vol. 147. P. 221-244.

Zhao W. W., Andreev A. A., Wennrich V., Tarasov P. E., Anderson P., Lozhkin A. V., Melles M. The Réunion Subchron vegetation and climate history of the northeastern Russian Arctic inferred from the Lake El'gygytgyn pollen record // Palaeogeography, Palaeoclimatology, Palaeoecology. 2015. Vol. 436. P. 167-177.

Zhao W. W., Tarasov P. E., Lozhkin A. V., Anderson P. M., Andreev A. A., Korzun Yu. A., Melles M., Nedorubova E. Yu., Wennrich $V$. High-latitude vegetation and climate changes during the Mid-Pleistocene Transition inferred from a high-resolution palynological record from Lake El'gygytgyn, northeastern Siberia // Boreas. 2017. Vol. 47. P. 137-149. 